\title{
The Interactions Between Plasma Membrane Depolarization and Glutamate Receptor Activation in the Regulation of Cytoplasmic Free Calcium in Cultured Cerebellar Granule Cells
}

\author{
Michael J. Courtney, ${ }^{1}$ Jeremy J. Lambert, ${ }^{2}$ and David G. Nicholls ${ }^{1}$ \\ Departments of ${ }^{1}$ Biochemistry and ${ }^{2}$ Pharmacology and Clinical Pharmacology, University of Dundee, Dundee, DD1 4HN, \\ Scotland, U.K.
}

\begin{abstract}
The complex modulation of cytoplasmic free calcium concentration $\left(\left[\mathrm{Ca}^{2+}\right]_{c}\right)$ in primary cultures of cerebellar granule cells in response to glutamate receptor agonists has been the subject of several contradictory reports. We here show that 3 components of the $\left[\mathrm{Ca}^{2+}\right]_{c}$ response can be distinguished: (1) $\mathrm{Ca}^{2+}$ entry through voltage-dependent $\mathrm{Ca}^{2+}$ channels, following $\mathrm{KCl}^{-}$or receptor-evoked depolarization, (2) $\mathrm{Ca}^{2+}$ entry through NMDA receptor channels, and (3) liberation of internal $\mathrm{Ca}^{2+}$ via a metabolotropic receptor. Depolarization with $\mathrm{KCl}$ induced a transient $\left[\mathrm{Ca}^{2+}\right]_{c}$ response (subject to voltage inactivation) decaying to a sustained plateau (largely inhibited by nifedipine). The NMDA response was potentiated by glycine, totally inhibited by $(+) 5$-methyl10,11-dihydro-5H-dibenzo[a,d]cyclohepten-5,10-imine maleate (MK-801), and blocked by $\mathbf{M g}^{2}$ । in a voltage-sensitive manner. Polarized cells displayed small responses to quisqualate (QA) and $\alpha$-amino-3-hydroxy-5-methyl-4-isoxazolepropionic acid (AMPA). Depolarization enhanced a transient response to QA, but not to AMPA. Trans-1-amino-1,3-cyclopentanedicarboxylic acid (trans-ACPD), a selective agonist for the metabolotropic glutamate receptor, caused a transient elevation of $\left[\mathrm{Ca}^{2+}\right]_{c}$, which was blocked by prior exposure to QA but not AMPA. The prolonged $\left[\mathrm{Ca}^{2+}\right]_{c}$ response to kainate (KA) can be resolved into 2 major components: an indirect NMDA receptor-mediated response due to released glutamate and a nifedipine-sensitive component consistent with depolarization-mediated entry via $\mathrm{Ca}^{2+}$ channels. 6-Cyano-7-nitroquinoxaline-2,3-dione (CNQX), QA at $>10 \mu \mathrm{M}$, and AMPA (but not trans-ACPD) reversed the KA response, consistent with an inactivation of the KA receptor. Our results show that the $\left[\mathrm{Ca}^{2}\right]_{c}$ responses to individual agonists involve complex interactions, suggesting that great care is required in the interpretation of agonist-stimulated cellular responses.
\end{abstract}

The cerebellar granule cell is the most numerous neuronal subtype in the mammalian brain (for review, see Burgoyne and Cambray-Deakin, 1988). It differentiates later than most other

\footnotetext{
Received Apr. 27, 1990; revised July 20, 1990; accepted Aug. 2, 1990.

This work was supported by the Science and Engineering Research Council and by Merck, Sharp and Dohme Research Laboratories, Harlow, U.K. We wish the thank Dr. Holopainen for access to papers in press and Dr. A. C. Dolphin for help with the culture technique.

Correspondence should be addressed to D. G. Nicholls, Department of Biochemistry, University of Dundee, Dundee, DD1 4HN, Scotland, United Kingdom. Copyright @ 1990 Society for Neuroscience $0270-6474 / 90 / 123873-07 \$ 03.00 / 0$
}

neurons, facilitating the production of primary cultures of high purity. The cells respond to the selective glutamate agonists NMDA, $\alpha$-amino-3-hydroxy-5-methyl-4-isoxazolepropionic acid (AMPA), and kainate (KA; Wroblewski et al., 1985; Drejer et al., 1986; Cull-Candy et al., 1988; Holopainen et al., 1989). Primary cultures of cerebellar granule cells have been extensively exploited in order to investigate the roles of the subclasses of glutamate receptors in the control of plasma membrane potential (Connor et al., 1987); the elevation of second messengers such as $\mathrm{Ca}^{2+}$ (Connor et al., 1987; Burgoyne et al., 1988; Bouchelouche et al., 1989; Holopainen et al., 1989; Wroblewski et al., 1989), inositol phosphates (Nicoletti et al., 1986a,b; Bouchelouche et al., 1989), and cGMP (Nicoletti et al., 1986b; McCalsin and Morgan, 1987; Novelli et al., 1987); the release of amino acids (Gallo et al., 1987a,b, 1989); and the regulation of gene expression (Szekely et al., 1989).

Electrophysiological studies on a variety of neurones indicate that, of the glutamate receptors, only the NMDA receptor can conduct $\mathrm{Ca}^{2+}$ directly, while the non-NMDA receptors conduct monovalent cations (Ascher and Nowak, 1987). Additionally, the recently described metabolotropic glutamate receptor (Sladeczek et al., 1985; Murphy and Miller, 1988) can elevate inositol phosphate concentrations and liberate $\mathrm{Ca}^{2+}$ from internal stores. Applied to the cerebellar granule cell, this scheme would predict that the $\left[\mathrm{Ca}^{2+}\right]_{c}$ response to NMDA might have $2 \mathrm{com}-$ ponents: one due to direct $\mathrm{Ca}^{2+}$ entry through the receptor channel, and one indirect component due to receptor-mediated depolarization-activating voltage-sensitive calcium channels. AMPA and $\mathrm{KA}\left[\mathrm{Ca}^{2+}\right]_{c}$ responses should be purely via the latter mechanism, the exact nature of which will depend on the spatial rclationships between the depolarizing receptors and the voltage-sensitive calcium channels. The quisqualate $(\mathrm{QA})\left[\mathrm{Ca}^{2+}\right]_{c}$ response should have components due both to depolarization and to mobilization of internal $\mathrm{Ca}^{2+}$ stores.

Elevated $\left[\mathrm{Ca}^{2+}\right]_{c}$ may in turn influence tertiary messengers. Thus, there are indications that increases in $\left[\mathrm{Ca}^{2+}\right]_{c}$, by whatever mechanism, are capable of activating inositol phosphate turnover directly as well as via release of transmitter onto metabolotropic receptors (Nahorski et al., 1986). Increased $\left[\mathrm{Ca}^{2+}\right]_{c}$ may also modulate cGMP levels (Novelli et al., 1987), gene expression (Szekely et al., 1989), and arachidonate production (Lazarewicz et al., 1988).

Published reports have proposed a more complex interaction between cerebellar granule cell glutamate receptors and second messengers than would be predicted. Thus, it has been reported that non-NMDA receptors may allow direct entry of $\mathrm{Ca}^{2+}$ across 
the plasma membrane (Holopainen et al., 1989), while direct coupling of glutamate receptors to a cGMP second-messenger system has been frequently discussed (Nicoletti et al., 1986b; Novelli et al., 1987), as has the possibility that glutamate receptors other than the metabolotropic QA receptor might be linked to phosphoinositide turnover (Nicoletti et al., 1986a,b). Furthermore, a number of groups have reported that cerebellar granule cells fail to increase $\left[\mathrm{Ca}^{2+}\right]_{c}$ in response to QA (Connor et al., 1987; Bouchelouche et al., 1989), KA (Bouchelouche et al., 1989), or NMDA (Connor et al., 1987; Bouchelouche et al., 1989), even in the absence of $\mathbf{M g}^{2+}$.

In this paper, we dissect systematically the separate components of the $\left[\mathrm{Ca}^{2+}\right]_{c}$ response of the cells, by considering first the response to $\mathrm{KCl}$ depolarization in the absence of receptor activation, then examining the effects of the individual glutamate receptors sequentially. We find that, when proper account is taken of the complex interactions between voltage- and receptor-mediated responses, the results are entirely consistent with the simple extrapolation from electrophysiological data discussed above.

\section{Materials and Methods}

Primary cultures. Cells were prepared essentially as described by Dutton et al. (1981). Briefly, cerebella from 8-d-old Wistar rats were pooled in buffer consisting of $153 \mathrm{mM} \mathrm{Na}^{+}, 4 \mathrm{mM} \mathrm{K}+, 1.5 \mathrm{mM} \mathrm{Mg}^{2+}, 139 \mathrm{mM}$ $\mathrm{Cl}^{-}, 10 \mathrm{mM} \mathrm{PO}_{4}{ }^{2-}, 1.5 \mathrm{mM} \mathrm{SO}_{4}{ }^{2-}, 14 \mathrm{mM}$ glucose, and $50 \mu \mathrm{M} \mathrm{BSA}(\mathrm{pH}$, 7.4). They were then chopped with 2 passes through a McIlwain tissue chopper into $375-\mu \mathrm{m}$ blocks, gently dispersed into buffer supplemented with $0.25 \mathrm{mg} / \mathrm{ml}$ trypsin, and incubated for $20 \mathrm{~min}$ at $37^{\circ} \mathrm{C}$. The trypsinization was terminated by addition of an equal volume of buffer containing $8 \mu \mathrm{g} / \mathrm{ml}$ soybean trypsin inhibitor and $8 \mathrm{U} / \mathrm{ml}$ DNAase I and centrifuged at $65 \times g$ for $30 \mathrm{sec}$. The supernatant was discarded, and the pellet was triturated 10 times, using a fire-polished Pasteur pipette with a narrowed end, in $1 \mathrm{ml}$ triturating medium (buffer containing $3 \mathrm{mM} \mathrm{Mg}^{2+}$ and $\mathrm{SO}_{4}{ }^{2-}$ supplemented with $50 \mu \mathrm{g} / \mathrm{ml}$ soybean trypsin inhibitor and $50 \mathrm{U} / \mathrm{ml}$ DNAase I). Material remaining in suspension was transferred to another tube, $1 \mathrm{ml}$ more triturating medium was added, and trituration was repeated. Perikarya were sedimented by underlying the supernatant with $2 \mathrm{ml} 4 \% \mathrm{BSA}$ in $\mathrm{Ca}^{2+}$-free Earle's Balanced Salts Solution and centrifuging for $5 \mathrm{~min}$ at $100 \times \mathrm{g}$. The pellet was resuspended in culture medium at a density of $10^{6} \mathrm{cells} / \mathrm{ml}$.

Cells were then plated at 750,000 per $\mathrm{cm}^{2}$ onto $13-\mathrm{mm}$-diameter, poly-L-lysine-coated circular coverslips. More culture medium was added approximately $12 \mathrm{hr}$ after plating. The culture medium consisted of Minimal Essential Medium (MEM) supplemented with $10 \%(v / v)$ fetal calf serum, $20 \mathrm{~mm} \mathrm{KCl}, 30 \mathrm{~mm}$ glucose, $2 \mathrm{mM}$ glutamine, $50 \mathrm{U} / \mathrm{ml}$ penicillin, and $50 \mu \mathrm{M}$ streptomycin. On the second day in vitro (2 DIV), $80 \mu \mathrm{M} 5$-fluoro-2'-deoxyuridine was added to the cultures to inhibit the replication of non-neuronal cells. The cultures were maintained at $37^{\circ} \mathrm{C}$ in a humidified atmosphere of $5 \% \mathrm{CO}_{2}: 95 \%$ air. Medium was replaced every 3-4 d.

Determination of $\left[\mathrm{Ca}^{2+}\right]_{\mathrm{c}}$. Coverslips were washed with modified Elliot's medium (127 $\mathrm{mM} \mathrm{Na}^{+}, 3.5 \mathrm{mM} \mathrm{K} \mathrm{K}^{+}, 1.3 \mathrm{mM} \mathrm{Ca}^{2+}, 1.2 \mathrm{mM} \mathrm{Mg} \mathrm{Mg}^{2+}$, $127.7 \mathrm{~mm} \mathrm{Cl}^{-}, 20 \mathrm{~mm} 2-\{[$ tris-(hydroxymethyl)-methyl]-amino\}-eth-

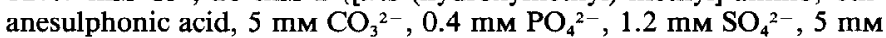
glucose, and $16 \mu \mathrm{M} \mathrm{BSA}, \mathrm{pH}$ 7.4) and transferred to stirred thermostatted plastic fluorescence cuvettes containing $1.5 \mathrm{ml}$ of this medium in an LS5-B Perkin Elmer luminescence spectrometer. The background fluorescence was measured, and the cells were then incubated with $3 \mu \mathrm{M}$ fura-2-acetoxymethyl ester (fura-2/AM) for 30-40 min. Cells were again washed in the cuvette. The emission at $505 \mathrm{~nm}$ was determined with alternate excitation at 340 and $380 \mathrm{~nm}$ (7.5-sec cycle time), and data points were collected in an IBM-compatible PC. At the end of each experiment, calibration was performed by exchanging the incubation medium for a $\mathrm{Mg}^{2+} / \mathrm{Ca}^{2+}$-free medium supplemented with $1 \mathrm{mM}$ EGTA $(\mathrm{pH}, 8.0) ; 10 \mu \mathrm{M}$ ionomycin was added to facilitate equilibration with the internal $\mathrm{Ca}^{2+}$ (zero $\left[\mathrm{Ca}^{2+}\right]_{c}$ ). Four $\mathrm{mm} \mathrm{CaCl}_{2}$ was then added to provide the reading corresponding to saturating $\left[\mathrm{Ca}^{2+}\right]_{c}$. The $K_{d}$ of hy- drolyzed fura-2 for $\mathrm{Ca}^{2}$ ' was laken to be 224 nM (Grynkiewicz et al., 1985).

Materials. Fura-2/AM and ionomycin were obtained from Calbiochem (Nottingham, U.K.). QA (synthetic) was obtained from Cambridge Research Biochemicals (Harston, Cambridge, U.K.). Penicillin/ streptomycin and phosphate-buffered salts were from Flow Laboratories Ltd. (Irvine, Ayrshire, U.K.). Fetal calf serum and MEM were from Gibco BRL (Paisley, Strathclyde, U.K.). 6-Cyano-7-nitroquinoxaline2,3-dione (CNQX) and (+)5-methyl-10,11-dihydro-5H-dibenzo [a,d]cyclohepten-5,10-imine maleate (MK-801) were donated by Dr. I. Ragan, Merck, Sharpe and Dohme Research Laboratory (Harlow, Essex, U.K.). Earle's Balanced Salts Solution was from Northumbria Biologicals Ltd. (Cramlington, Northumberland, U.K.). AMPA was from Research Biochemicals Inc. (SEMAT, St. Albans, Hertfordshire, U.K.). 1-Hydroxy-3-aminopyrrolid-2-one (HA-966) and trans-1-amino-1,3cyclopentanedicarboxylic acid (trans-ACPD) were from Tocris Neuramin (Buckhurst Hill, Essex, U.K.). Other reagents were from Sigma Chemical Co. (Poole, Dorset, U.K.).

\section{Results}

\section{$\mathrm{KCl}$ depolarization}

The indicated resting $\left[\mathrm{Ca}^{2+}\right]_{c}$ in polarized cells was $14 \pm 5 \mathrm{nM}$ $(n=24)$. It should be emphasized that this absolute value may be inaccurate because it is more than an order of magnitude below the $K_{d}$ for fura-2 (Grynkiewicz et al., 1985). Granule cells have been reported to maintain lower $\left[\mathrm{Ca}^{2+}\right]_{c}$ than Purkinje cells in culture (Connor and Tseng, 1988). As the cells are, of necessity, cultured under partially depolarizing conditions in order to elevate $\left[\mathrm{Ca}^{2+}\right]_{c}$ (Balázs et al., 1988), they may be expected to maintain a particularly low steady-state $\left[\mathrm{Ca}^{2+}\right]_{c}$ when returned to nondepolarizing media.

Raising the external $\left[\mathrm{K}^{+}\right]$from 3.5 to $33.5 \mathrm{~mm}$ produced a biphasic $\left[\mathrm{Ca}^{2+}\right]_{c}$ response in cells 5-9 DIV (Fig. $1 A$ ) to an initial transient of $329 \pm 76 \mathrm{nM}(n=13)$, followed by a recovery to a noninactivating plateau of $123 \perp 14 \mathrm{~nm}(n=13)$. The latter indicates the presence of a population of noninactivating voltage-sensitive calcium channels, and $67+11 \%(n=10)$ of this rise was inhibited by $1 \mu \mathrm{M}$ nifedipine (Fig. $1 A$ ). Less extensive depolarization by $10 \mathrm{~mm} \mathrm{KCl}$ caused a substantially smaller transient response, and also a smaller nifedipine-sensitive plateau (data not shown). When the dihydropyridine antagonist was added before depolarization (Fig. 1C), the transient was largely unaffected, while the plateau was depressed. Connor et al. (1987) have reported that cerebellar granule cells in explant culture undergo a series of action potentials in the 20-30 sec following $\mathrm{KCl}$ addition. This does not appear to occur in primary cell culture, because the large transient and plateau are both unaffected by tetrodotoxin (data not shown).

The decay of the transient appears to be due to a voltage inactivation of a class of transient $\mathrm{Ca}^{2+}$ channels. Thus, predepolarization in the absence of external $\mathrm{Ca}^{2+}$, followed by 1.3 mM CaCl , had no effect on the plateau of $\left[\mathrm{Ca}^{2+}\right]_{c}$, while greatly diminishing the transient (Fig. 1B). Carboni and Wojcik (1988) have reported that a comparable predepolarization of the cells blocks ${ }^{45} \mathrm{Ca}^{2+}$ influx. This suggests that the largest component of $\mathrm{Ca}^{2+}$ entry into the cells following depolarization occurs through the transient channels before they inactivate. Finally, the combination of predepolarization and nifedipine removed any remaining transient and further decreased the plateau (Fig. $1 D$ ). Thus, we can clearly distinguish 2 classes of $\mathrm{Ca}^{2+}$ channel in these cells: a dihydropyridine-sensitive L-channel, which is not inactivated by predepolarization but is sensitive to dihydropyridine antagonists, and an inactivating channel, which is nifedipine insensitive. 


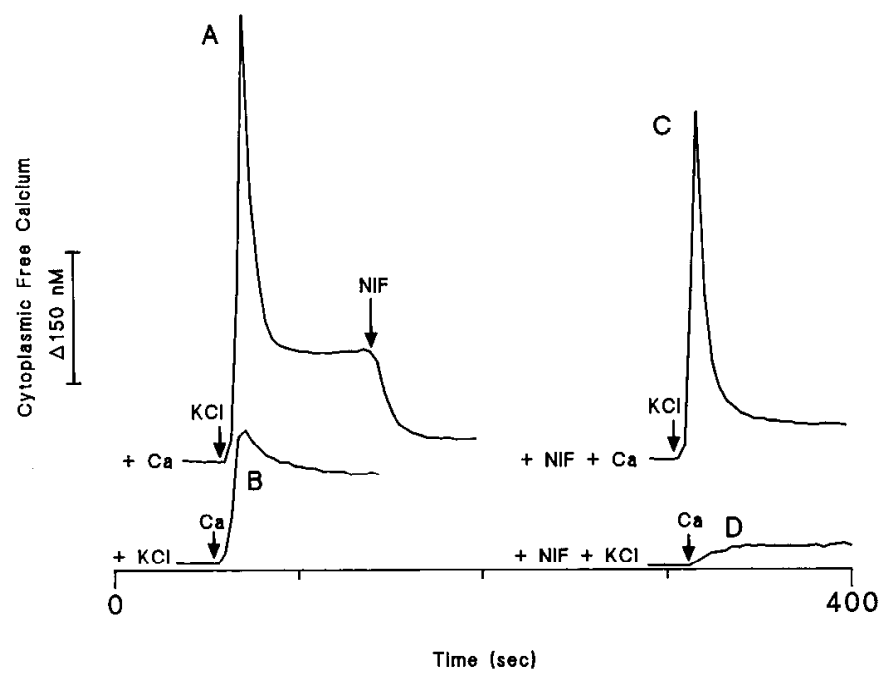

Figure 1. $\left[\mathrm{Ca}^{2+}\right]_{c}$ response of cerebellar granule cells to $\mathrm{KCl}$ depolarization. $A$, Biphasic response seen when $30 \mathrm{~mm} K C l$ was added to cells (5 DIV) in medium containing $1.3 \mathrm{mM} \mathrm{CaCl}_{2} ; 1 \mu \mathrm{M}$ nifedipine (NIF) was added where indicated. $B$, The component of the $\mathrm{KCl}$ response not inactivated by voltage was isolated by addition of $30 \mathrm{mM} \mathrm{KCl}$ to the cells in calcium-free medium containing $50 \mu \mathrm{M}$ EGTA prior to addition of $1.3 \mathrm{~mm} \mathrm{CaCl}_{2}$ (arrow). A small transient remains. $C$, The non-Lchannel responses are isolated by prior addition of $1 \mu \mathrm{M}$ nifedipine; the transient is not inhibited, but the plateau is substantially diminished. $D$, Prior addition of $1 \mu \mathrm{M}$ nifedipine to cells voltage-inactivated as in $B$ isolates a small noninactivating, non-dihydropyridine-sensitive component of the response. Traces are shifted vertically for clarity. $B$ and $D$ are corrected for the depolarization-independent rise in $\left[\mathrm{Ca}^{2+}\right]_{c}$ that occurs on addition of $1.3 \mathrm{~mm} \mathrm{Ca}$ to cells in polarized conditions.

\section{NMDA responses}

One hundred $\mu \mathrm{M}$ NMDA added to 9-DIV polarized cells in the absence of added $\mathrm{Mg}^{2+}$ gives a complex $\left[\mathrm{Ca}^{2+}\right]_{c}$ response (Fig. 2). Because activation of the NMDA receptor depolarizes the cells in addition to conducting $\mathrm{Ca}^{2+}$ (Ascher and Nowak, 1987), it is likely that this response is a combination of a $\mathrm{Ca}^{2}$ entry through the NMDA receptor and entry through voltage-sensitive calcium channels activated as a consequence of the depolarization. An extensive depolarization is also consistent with the subsequent failure of $0.4 \mathrm{mM} \mathrm{Mg}^{2+}$ to reverse the increase in $\left[\mathrm{Ca}^{2+}\right]_{c}$ (data not shown).

In order to dissect out a pure NMDA receptor response, lower concentrations of NMDA were added to cells that were only 6 DIV and possessed smaller responses to the agonist. Nifedipine was also added in order to block the L-channel component of any depolarization-activated $\mathrm{Ca}^{2+}$ entry (Fig. 3). Under these conditions, the absence of an initial spike indicates that any depolarization was not sufficient to activate the transient, nifedipine-insensitive $\mathrm{Ca}^{2+}$ channels.

The $\left[\mathrm{Ca}^{2+}\right]_{c}$ response to NMDA is consistent with the established electrophysiology of the patch-clamped receptors (Ascher and Nowak, 1987). Thus, the $\left[\mathrm{Ca}^{2+}\right]_{c}$ response in $\mathrm{Mg}^{2+}$-free medium is independent of $\mathrm{KCl}$ depolarization (Fig. 3). Furthermore, glycine enhances the NMDA-induced plateau; however, this is only clearly seen when HA-966, a competitive inhibitor at the glycine site (Foster and Kemp, 1989), is initially present to reduce the activation due to leaked endogenous glycine. The NMDA response was strongly inhibited by $0.4 \mathrm{~mm}$ $\mathrm{Mg}^{2+}$ in nondepolarized cells.

The NMDA antagonist MK-801 totally reverses the NMDA-

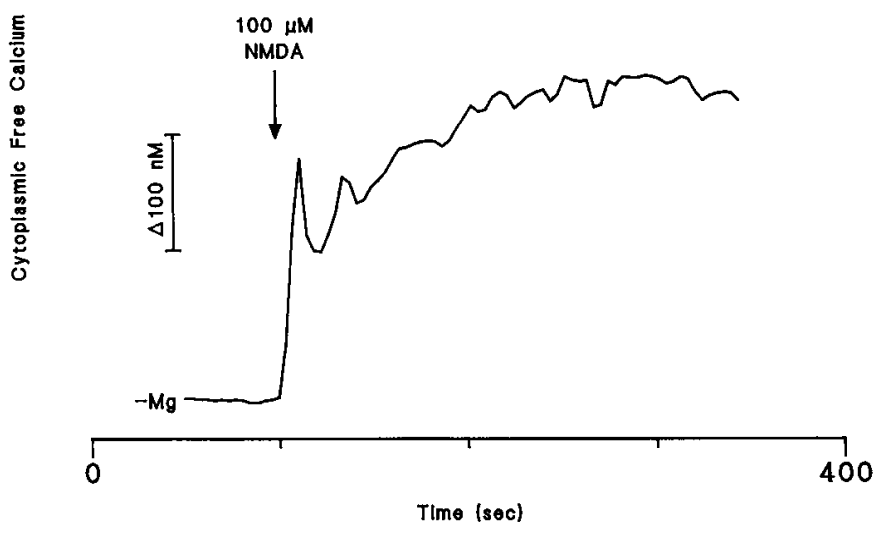

Figure 2. The complex response of 9-DIV cerebellar granule cells to $100 \mu \mathrm{M}$ NMDA (arrow) in $\mathrm{Mg}^{2+}$-free medium. A transient spike and slowly developing plateau of $\left[\mathrm{Ca}^{2+}\right]_{c}$ are observed.

induced response, under both polarized and depolarized conditions. The partial effect of $\mathrm{Mg}^{2+}$ on the response of the $\mathrm{KCl}$ depolarized cells is not due to a competitive inhibition of any residual voltage-sensitive calcium-channel activity because $\mathrm{Mg}^{2+}$ does not reduce the residual $\left[\mathrm{Ca}^{2+}\right]_{c}$ after MK-801 addition (data not shown). The possibility that glutamate released as a consequence of $\mathrm{KCl}$ depolarization might activate NMDA receptors and contribute to the $\left[\mathrm{Ca}^{2+}\right]_{c}$ plateau following $\mathrm{KCl}$ can be eliminated because $\mathrm{MK}-801$ did not affect the $\mathrm{KCl}$ plateau (data not shown).

\section{$A M P A$ and $Q A$ responses}

The response of the cells to AMPA or QA decreased with the age of the culture (Fig. 4). However, even with 5-DIV cells, the responses were much smaller than those seen with NMDA or KA (see below). Fifty $\mu$ M AMPA was maximal for increasing $\left[\mathrm{Ca}^{2+}\right]_{c}$ to a noninactivating plateau, whereas $10 \mu \mathrm{M}$ QA produced a biphasic response. At 9 DIV, little effect of AMPA or

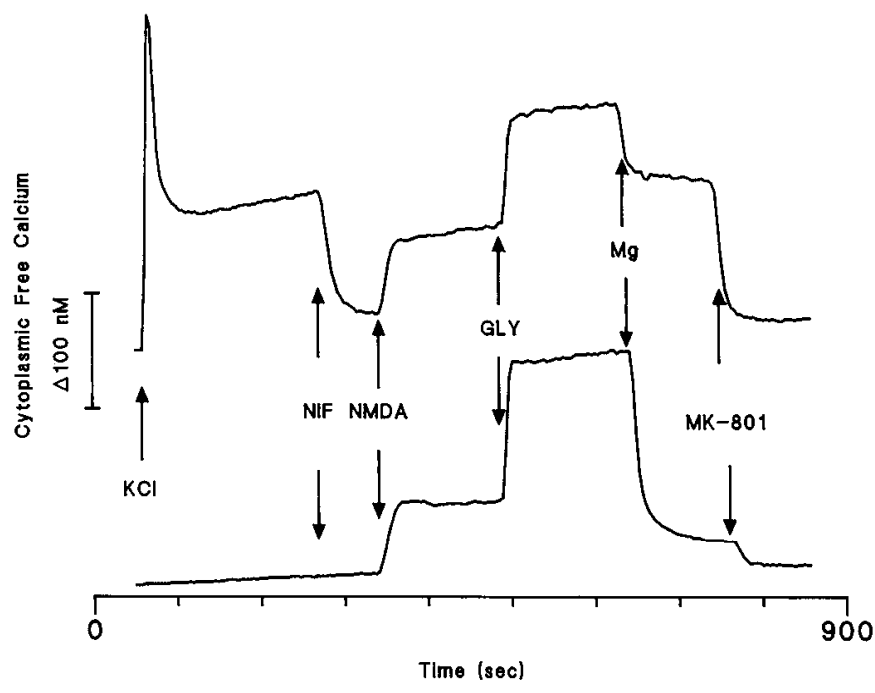

Figure 3. Modulation of NMDA response by voltage, glycine, $\mathbf{M g}^{2+}$, and MK-801 in 6-DIV cells. Cells were incubated in $\mathrm{Mg}^{2+}$-free medium in the presence of $100 \mu \mathrm{M}$ HA-966. Where shown (arrows), $30 \mathrm{mM} \mathrm{KCl}$ was added to the upper trace, and $50 \mu \mathrm{M}$ NMDA, $10 \mu \mathrm{M}$ glycine, 0.4 mM $\mathrm{MgCl}_{2}$, and $10 \mu \mathrm{M} \mathrm{MK}-801$ were added to both traces. 


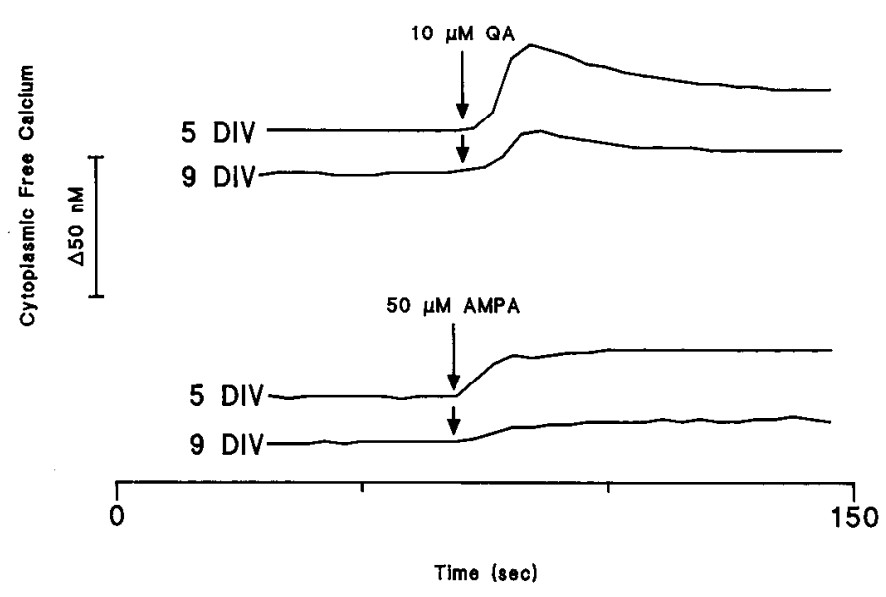

Figure 4. Devclopmental regulation of responses to $10 \mu \mathrm{M}$ QA and 50 $\mu_{\mathrm{M}}$ AMPA (arrows) in polarized cells. Upper traces of the pairs are from cells 5 DIV, and lower traces are from cells 9 DIV.

QA could be resolved with the polarized cells (Fig. 4); however, after $\mathrm{KCl}$-induced depolarization, $1 \mu \mathrm{M}$ QA caused a transient rise in $\left[\mathrm{Ca}^{2+}\right]_{c}$ (Fig. 5), which could not be mimicked by $150 \mu \mathrm{M}$ AMPA. The distinction between QA and AMPA suggests that the former, unlike the latter, may activate the metabolotropic QA receptor (Sladeczek et al., 1985) and liberate internal $\mathrm{Ca}^{2+}$ stores. Schoepp and Johnson (1988) have shown that QA, but not AMPA, can stimulate phosphoinositide hydrolysis, while Murphy and Miller (1988) have shown that the metabolotropic response in hippocampal neurons is maximal following $\mathrm{KCl}$ depolarization.

One hundred $\mu \mathrm{M}$ trans-ACPD, which has been reported to act as a specific metabolotropic QA receptor agonist (Palmer et al., 1989), produced a transient response in $\mathrm{KCl}$-depolarized cells (Figs. 5, 6). A second addition of the agonist was ineffective (data not shown). The response is still seen after $150 \mu \mathrm{M}$ AMPA (Fig. 5), but not after $1 \mu \mathrm{M}$ QA (Fig. 6). This suggests either that $\mathrm{QA}$ and trans-ACPD, but not AMPA, are capable of releasing $\mathrm{Ca}^{2+}$ from the same limited pool, or alternatively, that a com-

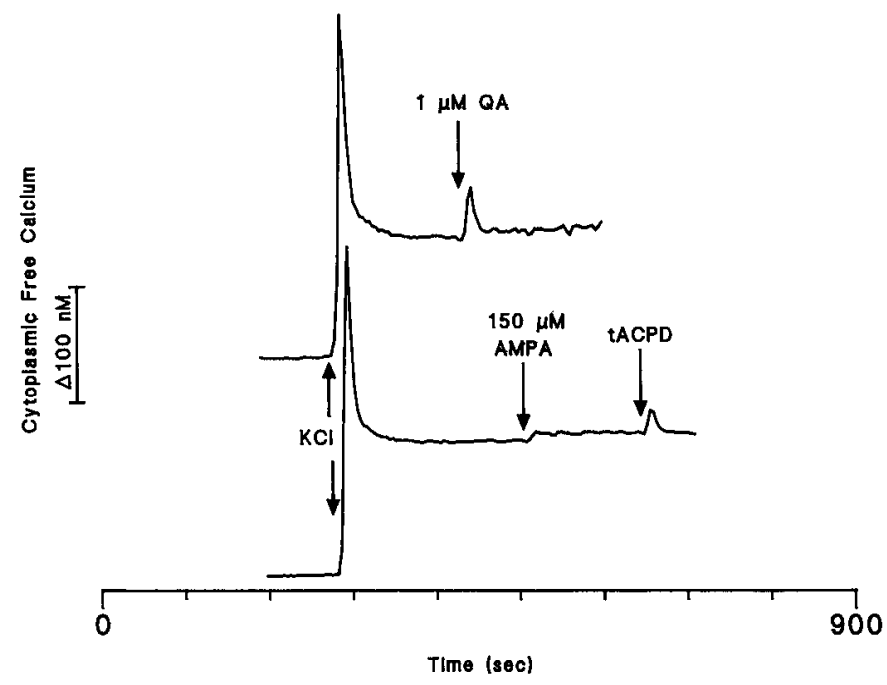

Figure 5. QA and trans-ACPD responses in depolarized cells at 9 DIV. Where shown (arrows), $30 \mathrm{mM} \mathrm{KCl}$ was added. One $\mu \mathrm{M} \mathrm{QA}$, or $150 \mu \mathrm{M}$ AMPA and $100 \mu \mathrm{M}$ trans-ACPD $(t A C P D)$, were added subsequently as shown.

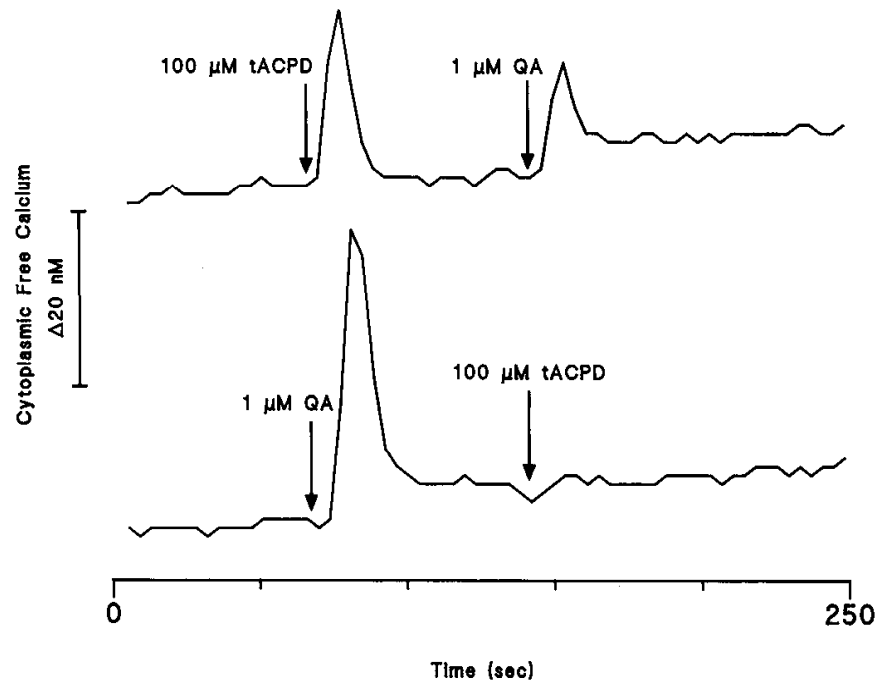

Figure 6. Trans-ACPD is ineffective after QA addition (arrows) to depolarized 9-DIV cells, and QA response is diminished after transACPD $(t A C P D)$. Before the start of both traces, the cells were depolarized by the addition of $30 \mathrm{~mm} \mathrm{KCl}$.

mon receptor rapidly inactivates. QA can still increase $\left[\mathrm{Ca}^{2+}\right]_{c}$ after excess trans-ACPD (Fig. 6), though the magnitude of the response is decreased. This may correspond to the AMPA receptor component of the QA response.

\section{$K A$ responses}

The complex response of 7-DIV cells to $100 \mu \mathrm{M} \mathrm{KA}$ in the absence of $\mathrm{Mg}^{2+}$ is illustrated in Figure 7. In the presence of MK-801 to inhibit the NMDA receptor, the response appears much more homogeneous. This indicates that, under these conditions, there is a partial activation of NMDA receptors. KA could either (1) be acting directly on NMDA receptors, (2) release endogenous glutamate onto NMDA receptors as a result of depolarization and activation of exocytosis, or (3) release cytoplasmic glutamate and aspartate either by reversal of the $\mathrm{Na}^{+}$-coupled acidic amino acid carrier due to increased internal $\mathrm{Na}^{+}$or by blocking reuptake of leaked amino acids through the carrier. Option 2 can be eliminated because any glutamate released by $30 \mathrm{~mm} \mathrm{KCl}$ does not produce an $\mathrm{MK}-801$-sensitive component in the $\left[\mathrm{Ca}^{2+}\right]_{c}$ response (see above); carrier blockade can be eliminated because an equal concentration of dihydrokainate, which is a more potent inhibitor of the acidic amino acid carrier but a weaker KA receptor agonist (Johnston et al., 1979), did not cause a $\left[\mathrm{Ca}^{2+}\right]_{c}$ response in these cultures (data not shown).

Two $\mu \mathrm{M}$ CNQX, a concentration of this "nonspecific nonNMDA antagonist" that does not affect the NMDA receptor (Watkins et al., 1990), reversed both components of the kainateevoked $\left[\mathrm{Ca}^{2+}\right]_{c}$ increase (data not shown). Thus, it seems likely that the MK-801-sensitive component is due to an indirect action of amino acids released from the cytoplasm as a consequence of KA allowing $\mathrm{Na}^{+}$entry, lowering the $\mathrm{Na}^{+}$electrochemical gradient and reversing the plasma-membrane acidic amino acid carrier, rather than a direct action of kainate on the granule-cell NMDA receptor. It should be noted that $100 \mu \mathrm{M}$ $\mathrm{KA}$ is insufficient to inhibit the acidic amino acid carrier (Johnston et al., 1979).

In contrast to earlier reports (Holopainen et al., 1989), the 


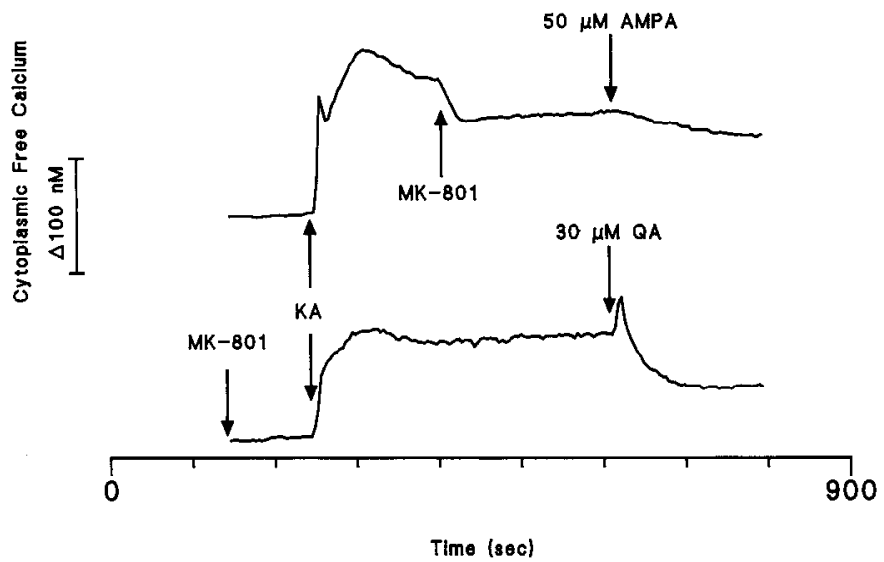

Figure 7. KA responses in 7-DIV cells in absence of $\mathrm{Mg}^{2+}$. In the lower trace, $10 \mu \mathbf{M}$ MK-801 was initially present. One hundred $\mu \mathrm{M}$ KA, 10 $\mu \mathrm{M}$ MK-801, $50 \mu \mathrm{M}$ AMPA, and $30 \mu \mathrm{M}$ QA were added as indicated (arrows).

KA plateau could be strongly inhibited by a $\mathrm{Ca}^{2+}$ channel antagonist, nifedipine at $1 \mu \mathrm{M}$ (Fig. $8 \mathrm{~B}$ ), consistent with $\mathrm{Ca}^{2+}$ entry through activation of voltage-sensitive calcium channels rather than direct conductance through the KA channel itself. The absence of an extensive initial $\left[\mathrm{Ca}^{2+}\right]_{c}$ transient in the pure KA response may reflect either an insufficient depolarization to activate the transient voltage-sensitive calcium current that is seen with $\mathrm{KCl}$ or a differential localization of the $\mathrm{KA}$ receptors and transient $\mathrm{Ca}^{2+}$ channels within the cell.

\section{Interaction between $Q A$ and $K A$ responses}

Thirty $\mu \mathrm{M}$ QA superimposed a transient rise in $\left[\mathrm{Ca}^{2+}\right]_{c}$ onto the $\mathrm{KA}$ plateau similar to that produced by QA following $\mathrm{KCl}$ depolarization (Fig. 5). However, immediately following this transient, a strong, persistent inhibition of the KA plateau was seen (Fig. 7). AMPA at $50 \mu \mathrm{M}$ produced a slow inhibition but no initial transient (Fig. 7). With $150 \mu \mathrm{M}$ AMPA, the inhibition was as rapid and extensive as that seen with $30 \mu \mathrm{M}$ QA, though again, no transient occurred (data not shown).

After KA, the transient with $30 \mu \mathrm{M}$ QA is no larger than that with $1 \mu \mathrm{M}$ agonist (Fig. 8C) and is also mimicked by $100 \mu \mathrm{M}$ trans-ACPD (data not shown). However, $1 \mu \mathrm{M}$ QA (Fig. 8C) or $100 \mu \mathrm{M}$ trans-ACPD (not shown) did not cause a subsequent inhibition, which required much higher concentrations of QA. CNQX, however, inhibits the KA response at $2 \mu \mathrm{M}$ (Fig. 8A). No further inhibition was produced by additional CNQX, 30 $\mu \mathrm{M}$ QA, or $1 \mu \mathrm{M}$ nifedipine (data not shown). The residual $\left[\mathrm{Ca}^{2+}\right]_{c}$ after CNQX is similar to that after nifedipine (Fig. $8 B$ ), suggesting that any residual nifedipine-insensitive $\left[\mathrm{Ca}^{2+}\right]_{c}$ is not associated with the KA receptor. Preexposure of the cells to 30 $\mu \mathrm{M} \mathrm{QA}$, or to $2 \mu \mathrm{M} \mathrm{CNQX}$, strongly inhibited the KA response (data not shown).

\section{Discussion}

The present results are consistent with 3 modes of $\mathrm{Ca}^{2+}$ entry into the cytoplasm following glutamate receptor activation: (1) a direct $\mathrm{Ca}^{2+}$ entry through NMDA receptor channels, characterized by a retained $\mathrm{Ca}^{2+}$ signal in the presence of nifedipine after transient, nifedipine-insensitive channels have voltage inactivated (Fig. 3); (2) an indirect entry of $\mathrm{Ca}^{2+}$ through voltagesensitive calcium channels as a consequence of $\mathrm{KA}$ receptormediated depolarization of the plasma membrane, character-

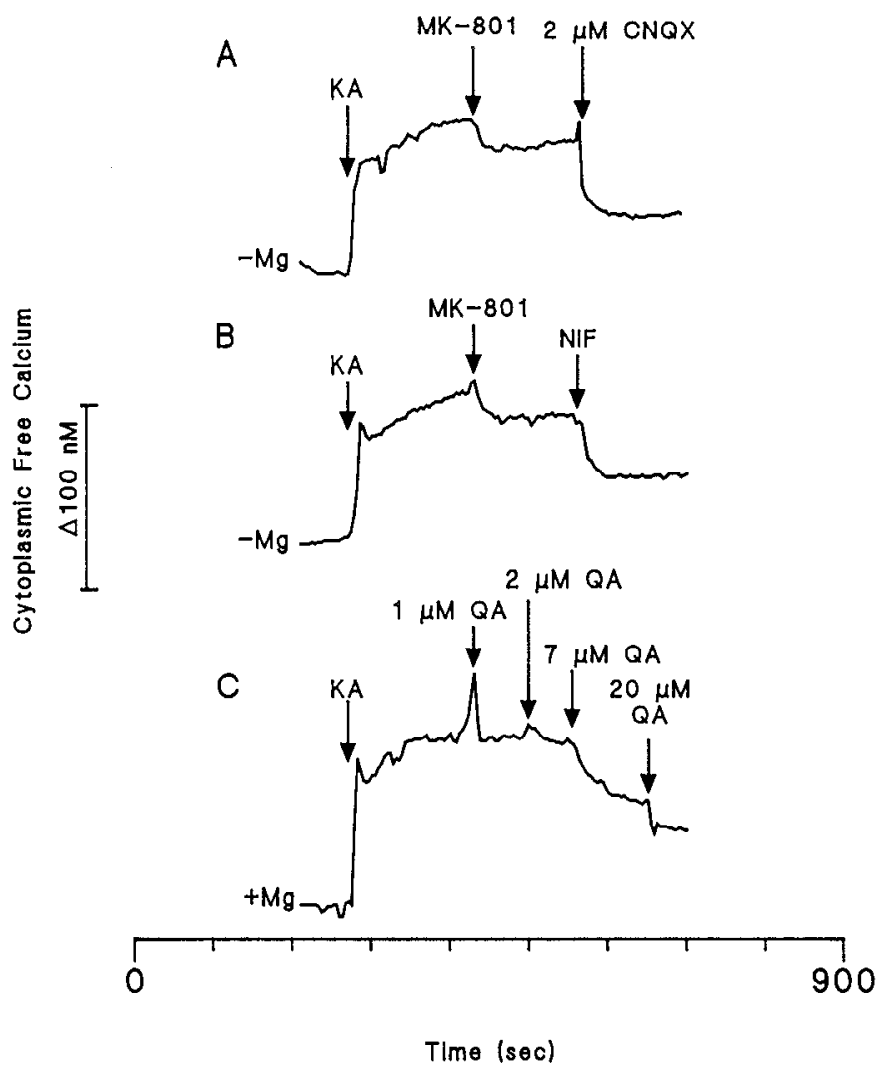

Figure 8. Sensitivity of $\mathbf{M g}^{2+} / \mathrm{MK}-801-$ resistant component of KA response to CNQX, nifedipine, and QA. $A$ and $B$, Cells 6 DIV in $\mathrm{Mg}^{2+}$. free medium; $2 \mu \mathrm{M} C N Q X$ or $1 \mu \mathrm{M}$ nifedipine were added where indicated (arrows). $C$, Cells $7 \mathrm{DIV}$ in $\mathrm{Mg}^{2+}$-containing medium; $100 \mu \mathrm{M}$ $\mathrm{KA}$ was added followed by sequential QA additions (arrows). Note that the first addition gives a transient spike, whereas subsequent additions cause a progressive inhibition of the KA response.

ized by the same high sensitivity to nifedipine of both the KA- (Fig. 8) and KCl-evoked (Fig. 1) $\mathrm{Ca}^{2+}$ elevations and by the ability of nifedipine to inhibit the KA response as effectively as does the KA receptor antagonist CNQX (Fig. 8); and (3) a transient increase in $\left[\mathrm{Ca}^{2+}\right]_{c}$ evoked by trans-ACPD or by a nonAMPA receptor effect of QA, which is only seen subsequent to plasma membrane depolarization and is consistent with the mobilization of internal $\mathrm{Ca}^{2+}$ by the metabolotropic QA receptor (Sladeczek et al., 1985).

\section{Heterogeneous voltage-sensitive $\mathrm{Ca}^{2+}$ channels}

We have been able to dissect 2 components of the voltagesensitive calcium channel response: a transient, voltageinactivated, dihydropyridine-insensitive channel and a largely noninactivating dihydropyridine-sensitive L-channel. This heterogeneity can explain reports in the literature concerning incomplete dihydropyridine antagonist sensitivity of ${ }^{45} \mathrm{Ca}^{2+}$ entry (Kingsbury and Balázs, 1987; Carboni and Wojcik, 1988). The initial transient channel may transport the bulk of the $\mathrm{Ca}^{2+}$ into the cell, because Carboni and Wojcik (1988) reported that 20 sec of predepolarization strongly inhibited ${ }^{45} \mathrm{Ca}^{2+}$ entry into 8 9-DIV cerebellar granule cells.

$N M D A$ receptor-mediated elevation in $\left[\mathrm{Ca}^{2+}\right]_{\mathrm{c}}$

Because the NMDA receptor allows the entry of monovalent cations in addition to $\mathrm{Ca}^{2+}$ (Ascher and Nowak, 1987), it is 
essential to distinguish between a primary entry of $\mathrm{Ca}^{2+}$ through the receptor channel and a secondary entry through voltagesensitive calcium channels as a consequence of the depolarization. We have adopted 2 strategies to eliminate the latter: first, the use of nifedipine to inhibit the noninactivating $L$-channels, and, second, employing suboptimal NMDA concentrations with young (5-7-DIV) cells to limit the extent of depolarization. Only under these conditions was it possible to see a substantial $\mathrm{Mg}^{2+}$ blockade of the $\mathrm{Ca}^{2+}$ signal in nonpolarized cells. Glycine stimulation of the NMDA response (Johnson and Ascher, 1987) could only be clearly demonstrated in the presence of sufficient glycine antagonist HA-966 (Foster and Kemp, 1989) to compete with endogenous glycine present in the cultures (Fig. 3).

\section{$A M P A-$ and $Q A$-mediated elevations in $\left[\mathrm{Ca}^{2+}\right]_{\mathrm{c}}$}

The $\left[\mathrm{Ca}^{2+}\right]_{c}$ responses to AMPA and QA in these cells are small relative to those seen with the other agonists and decrease with the age of the cells (Fig. 4). The AMPA response is noninactivating (Fig. 4) and can be detected in both polarized and depolarized cells; however, its small size makes us unable to distinguish between an effect on $\left[\mathrm{Ca}^{2+}\right]_{c}$ due to depolarization and activation of voltage-sensitive calcium channels or, as suggested by Holopainen et al. (1989), a direct entry of $\mathrm{Ca}^{2+}$ through the receptor-coupled ion channel.

The QA response is more complex (Fig. 4), even when the use of concentrations $(>10 \mu \mathrm{M})$ that activate the NMDA receptor (Holopainen et al., 1990) is avoided. First, in addition to an AMPA-like sustained elevation in $\left[\mathrm{Ca}^{2+}\right]_{c}$, a transient spike is seen, particularly in predepolarized cells (Fig. 5). This spike appears, at least in part, to be due to the activation of the "metabolotropic QA receptor" because trans-ACPD, which has been reported to be a specific agonist for this receptor (Palmer et al., 1989), mimics the transient response (Figs. 5, 6). Furthermore, prior exposure to trans-ACPD decreases the size of a subsequent QA spike (Fig. 6). Conversely, trans-ACPD is ineffective when added subsequently to QA (Fig. 6) but does generate a response following AMPA (Fig. 5), consistent with the inability of AMPA to activate the metabolotropic receptor (Schoepp and Johnson, 1988).

It is unlikely that the response we observe is due to a contamination with Purkinje cells, which are known to possess high concentrations of the metabolotropic QA receptor (Blackstone et al., 1989), because our cultures reveal no large cell bodies characteristic of Purkinje cells; this is consistent with the failure of these early-differentiating cells to survive postnatal isolation and culture (Weber and Schachner, 1984). There have been several reports of extensive, receptor-stimulated phosphoinositide hydrolysis and $\mathrm{IP}_{3}$ production in cerebellar granule cell cultures (Nicoletti et al., 1986a,b; Bouchelouche et al., 1989; Dillon-Carter and Chuang, 1989), though Ross et al. (1989) did not detect the presence of the putative inositol-1,4,5-trisphosphate receptor pp260 within the granule cell layer of the adult cerebellum by electron microscopic immunocytochemistry. As we observe a trans-ACPD-mediated $\mathrm{Ca}^{2+}$-transient in the granule cells, this suggests that they do possess significant inositol1,4,5-trisphosphate-mediated $\mathrm{Ca}^{2+}$ release mechanisms.

\section{$K A$-mediated elevations of $\left[\mathrm{Ca}^{2+}\right]$ 。}

The response of the cells to $100 \mu \mathrm{M} \mathrm{KA}$ is complex (Figs. 7, 8) and includes an NMDA receptor component that can be eliminated by MK-801 (Fig. 7) and a nifedipine-sensitive component (Fig. $8 B$ ). Both components are inhibited by the non-NMDA receptor antagonist CNQX at $2 \mu \mathrm{M}$, suggesting that the MK801 -sensitive component is not due to a direct action of KA on NMDA receptors, but rather to an activation of NMDA rcceptors by endogenous glutamate or aspartate released from the cells by the action of KA. The MK-801-insensitive, KA receptor-mediated plateau is inhibited by addition of QA or AMPA (Fig. 7), even in more mature (9-DIV or later) cultures that do not exhibit detectable AMPA receptor responses. The extent of inhibition with $30 \mu \mathrm{M}$ QA or $2 \mu \mathrm{M}$ CNQX is comparable to that produced by $1 \mu \mathrm{M}$ nifedipine (Fig. 8).

An inhibition of KA responses by QA has been reported by several groups in a variety of systems. Ishida and Neyton (1985) observed such an effect in retinal horizontal cells; Gallo et al. (1989) and McCaslin and Morgan (1987) have reported that high QA concentrations inhibit a KA response in cerebellar granule cells, the former group measuring ${ }^{3} \mathrm{H}$-D-aspartate release, the latter, cGMP production. It seems unlikely that the inhibitory effect of $30 \mu \mathrm{M}$ QA or $2 \mu \mathrm{M} C N Q X$ on the KA response is due to displacement of $100 \mu \mathrm{M} \mathrm{KA}$ from its receptor, because this would require QA and CNQX to have a far greater affinity for the KA receptor than KA itself, contrary to binding studies (Foster and Fagg, 1984; Watkins et al., 1990). There is clearly some kind of interaction between an AMPA/QA binding site and the $\mathrm{KA}$ receptor.

\section{Conclusions}

These results clearly show that the $\left[\mathrm{Ca}^{2+}\right]_{c}$ responses to stimulation of different glutamate receptors are mediated by a common set of basic mechanisms: depolarization-induced activation of a family of voltage-sensitive calcium channels, direct conduction of calcium into the cytoplasm through ligand-gated channels, and metabolotropic receptor-mediated release of calcium from internal stores. There are complex interactions between these systems. The KA receptor-mediated responses are inhibited by AMPA or QA, while KA receptor stimulation may release endogenous glutamate and activate NMDA receptors. These interactions, together with the limited selectivity of agonists and particularly antagonists for these receptors, substantially complicate the interpretation of any single observation of $\left[\mathrm{Ca}^{2+}\right]_{c}$ response.

There are reports in the literature of stimulation of inositol phosphate production in cerebellar granule cells by all the glutamate receptor agonists (Nicoletti et al., 1986a,b, 1988; Wroblewski et al., 1987). This has led to the hypothesis that there are 2 metabolotropic receptor subtypes, in addition to ionotropic receptor subtypes present in these cells. One, activated by QA and pertussis-toxin sensitive (Nicoletti et al., 1988), may mediate the trans-ACPD response we have detected. However, there has been little consideration of the possible role of $\left[\mathrm{Ca}^{2+}\right]_{c}$ elevation in both stimulating and potentiating inositol phosphate production, as has been observed in other systems ( Nahorski et al., 1986; Smart, 1989). Other glutamate receptormediated responses reported in these cells, such as production of cGMP (Novelli et al., 1987) and arachidonic acid (Lázarewicz et al., 1988), may also be secondary to elevation of $\left[\mathrm{Ca}^{2+}\right]_{c}$. An important control, which is rarely performed, would be to investigate whether depolarization by elevaled $\mathrm{KCl}$ can reproduce these secondary events by activating voltage-sensitive calcium channels and elevating $\left[\mathrm{Ca}^{2+}\right]_{c}$ independently of receptor activation. This would explain the apparent lack of specificity of the receptor subtypes for these responses. The role of each re- 
ceptor subtype in intracellular signaling may only be fully understood if their effects on $\left[\mathrm{Ca}^{2+}\right]_{c}$ are appreciated.

\section{References}

Ascher P, Nowak L (1987) Electrophysiological studies of NMDA receptors. Trends Neurosci 10:284-288.

Balázs R, Jörgensen OS, Hack N (1988) $N$-methyl-D-aspartate promotes the survival of cerebellar granule cells in culture. Neuroscience $27: 437-452$.

Blackstone CD, Supattapone S, Snyder SH (1989) Inositol phospholipid-linked glutamate receptors mediate cerebellar parallel-fibre-Purkinje-cell synaptic transmission. Proc Natl Acad Sci USA 86:43164320.

Bouchelouche P, Belhage B, Frandsen A, Drejer J, Schousboe A (1989) Glutamate receptor activation in cultured cerebellar granule cells increases cytosolic free $\mathrm{Ca}^{2+}$ by mobilisation of cellular $\mathrm{Ca}^{2+}$ and activation of $\mathrm{Ca}^{2+}$ influx. Exp Brain Res 76:281-29l.

Burgoyne RD, Cambray-Deakin MA (1988) The cellular neurobiology of neuronal development: the cerebellar granule cell. Brain Res Rev $13: 77-101$

Burgoyne RD, Pearce IA, Cambray-Deakin M (1988) N-methyl-Daspartate raises cytosolic calcium concentration in rat cerebellar granule cells in culture. Neurosci Lett 91:47-52.

Carboni E, Wojcik WJ (1988) Dihydropyridine binding sites regulate calcium influx through specific voltage-sensitive calcium channels in cerebellar granule cells. J Neurochem 50:1279-1286.

Connor JA, Tseng HY (1988) Measurement of intracellular $\mathrm{Ca}^{2+}$ in cerebellar Purkinje neurons in culture: resting distribution and response to glutamate. Brain Res Bull 21:353-361.

Connor JA, Tseng HY, Hockberger PE (1987) Depolarization- and transmitter-induced changes in intracellular $\mathrm{Ca}^{2+}$. J Neurosci 7:13841400 .

Cull-Candy SG, Howe JR, Ogden DC (1988) Noise and single channels activated by excitatory amino acids in cerebellar granule cells in explant culture. J Physiol (Lond) 400:189-222.

Dillon-Carter O, Chuang DM (1989) Homologous desensitization of muscarinic cholinergic histaminergic, adrenergic and serotonergic receptors coupled to phospholipase C in cerebellar granule cells. J Neurochem 52:598-603.

Drejer J, Honore T, Meier E, Schousboe A (1986) Pharmacologically distinct glutamate receptors on cerebellar granule cells. Life Sci 38: 2077-2085.

Dutton GR, Currie DN, Tear K (1981) An improved method for the bulk isolation of viable perikarya from postnatal cerebellum. J Neurosci Meth 3:421-427.

Foster AC, Fagg GE (1984) Acidic amino acid receptors. Brain Res Rev 7:103-164.

Foster AC, Kemp JA (1989) HA-966 antagonizes NMDA receptors through a selective interaction with the glycine modulatory site. J Neurosci 9:2191-2196.

Gallo V, Suergiu R, Levi G (1987a) Functional evaluation of glutamate receptor subtypes in cultured cerebellar neurones and astrocytes. Eur J Pharmacol 138:293-297.

Gallo V, Suergiu R, Giovannini C, Levi G (1987b) Glutamate receptor subtypes in cultured cerebellar neurones: modulation of glutamate and GABA release. J Neurochem 49:1801-1809.

Gallo V, Giovannini C, Levi G (1989) Quisqualic acid modulates kainate responses in cultured cerebellar granule cells. J Neurochem 52:10-16.

Grynkiewicz G, Poenie M, Tsien RY (1985) A new generation of Ca indicators with greatly improved fluorescence properties. J Biol Chem 260:3440-3450.

Holopainen I, Enkvist MOK, Åkerman KEO (1989) Glutamate receptor agonists increase intracellular $\mathrm{Ca}^{2+}$ independently of voltage gated Ca channels in rat cerebellar granule cells. Neurosci Lett 98: $57-62$.

Holopainen I, Louve M, Enkvist MOK, Åkerman KEO (1990) The coupling of glutamatergic receptors to changes in intracellular $\mathrm{Ca}^{2+}$ in rat cerebellar granule cells receptor agonists increase intracellular $\mathrm{Ca}^{21}$ independently of voltage gated $\mathrm{Ca}$ channels in rat cerebellar granule cells. J Neurosci Res 25:187-193.

Ishida AT, Neyton J (1985) Quisqualate and L-glutamate inhibit retinal horizontal cell responses to kainate. Proc Natl Acad Sci USA 82: $1837-1841$.
Johnson JW, Ascher P (1987) Glycine potentiates the NMDA response in cultured mouse brain neurons. Nature 325:522-525.

Johnston GAR, Kennedy SME, Twitchin B (1979) Action of the neurotoxin kainic acid on high aftinity uptake of $\mathrm{L}$-glutamic acid in rat brain slices. J Neurochem 32:121-127.

Kingsbury A, Balázs R (1987) Effect of calcium agonists and antagonists on cerebellar granule cells. Eur J Pharmacol 140:275-283.

Lazarewicz JW, Wroblewski JT, Palmer ME, Costa E (1988) Activation of $N$-methyl-D-aspartate-sensitive glutamate receptors stimulates arachidonic acid release in primary cultures of cerebellar granule cells. Neuropharmacology 27:765-769.

McCalsin PP, Morgan WW (1987) Cultured cerebellar cells as an in vitro model of excitatory amino acid receptor function. Brain Res 417:380-384

Murphy SN, Miller RJ (1988) A glutamate receptor regulates $\mathrm{Ca}^{2}$ । mobilisation in hippocampal neurons. Proc Natl Acad Sci USA 85: 8737-8741.

Nahorski SR, Kendall DA, Batty I (1986) Receptors and phosphoinositide metabolism in the central nervous system. Biochem Pharmacol 35:2447-2453.

Nicoletti F, Wroblewski JT, Novelli A, Alho H, Guidotti A, Costa E (1986a) The activation of inositol phospholipid metabolism as a signal-transducing system for excitatory amino acids in primary cultures of cerebellar granule cells. J Neurosci 6:1905-1911.

Nicoletti F, Wroblewski JT, Novelli A, Guidotti A, Costa E (1986b) Excitatory amino acid signal transduction in cerebellar cell cultures. Funct Neurol 1:345-349.

Nicoletti F, Wroblewski JT, Fadda E, Costa E (1988) Pertussis toxin inhibits signal transduction at a specific metabolotropic glutamate receptor in primary cultures of cerebellar granule cells. Neuropharmacology 27:551-556.

Novelli A, Nicoletti F, Wroblewski JT, Alho H, Costa E, Guidotti A (1987) Excitatory amino acid receptors coupled with guanylate cyclase ion primary cultures of cerebellar granule cells. J Neurosci 7: $40-47$.

Palmer E, Monaghan DT, Cotman CW (1989) Trans-ACPD, a selective agonist of the phosphoinositide-coupled excitatory amino acid receptor. Eur J Pharmacol 166:585-587.

Ross CA, Meldolesi J, Millner TA, Satoh T, Supattapone S, Snyder SH (1989) Inositol 1,4,5-trisphosphate receptor localiscd to endoplasmic reticulum in cerebellar Purkinje neurons. Nature 339:468-470.

Schoepp DD, Johnson BG (1988) Excitatory amino acid agonist-antagonist interactions at 2-amino-4-phosphonobutyric acid-sensitive quisqualate receptors coupled to phosphoinositide hydrolysis of rat hippocampus. J Neurochem 50:1605-1613.

Sladeczek F, Pin JP, Recasens M, Bockaert J, Weiss S (1985) Glutamate stimulates inositol phosphate formation in striatal neurones. Nature 317:717-719.

Smart TG (1989) Excitatory amino acids: the involvement of second messengers in the signal transduction process. Cell Mol Neurobiol 9: 193-206.

Szekely AM, Barbaccia BL, Alho H, Costa E (1989) In primary cultures of cerebellar granule cells the activation of $N$-methyl-D-aspartatesensitive glutamate receptors induces $c$-fos mRNA expression. Mol Pharmacol 35:401-408.

Watkins JC, Krogsgaard-Larsen P, Honore T (1990) Structure-activity relationships in the development of excitatory amino acid receptor agonists and competitive antagonists. Trends Neurosci 11:25-33.

Weber A, Schachner M (1984) Maintenance of immunocytologically identified Purkinje cells from mouse cerebellum in monolayer culture. Brain Res 311:119-130.

Wroblewski IT, Nicoletti F, Costa E (1985) Different coupling of excitory amino acid receptors with $\mathrm{Ca}^{2+}$ channels in primary cultures of cerebellar granule cells. Neuropharmacology 24:919-921.

Wroblewski JT, Nicoletti F, Fadda E, Costa E (1987) Phencyclidine is a negative allosteric modulator of signal transduction at two classes of excitatory amino acid receptors. Proc Natl Acad Sci USA 84:50685072 .

Wroblewski JT, Fadda E, Mazzetta J, Lazarewicz JW, Costa E (1989) Glycine and D-serine act as positive modulation of signal transduction at $N$-methyl-D-aspartate sensitive glutamate receptors in cultured cerebellar granule cells. Neuropharmacology 28:447-452. 